Department of Anatomy (Prof. T. FujITA), Niigata University School of Medicine, Niigata, Japan

\title{
Ferritin Labeling in the Fixed Muscle Capillary. A Doubt on the Tracer-Experiments as the Basis for the Vesicular Transport Theory
}

\author{
Shigeru Kobayashi（小林繁）
}

Received March 25, 1970

On the basis of his observations on the occurrence of characteristic caveolae and vesicles within the capillary endothelium, PALADE (1953) proposed an original hypothesis that substances are transported through the capillary endothelium enclosed in these vesicular structures which were presumed to move rapidly. The mechanism of "vesicular transport" was later named cytopempsis by Moore and RuskA (1957). This process consists of (1) engulfing substances from one surface by invaginations of the plasmalemma, (2) intracytoplasmic transport by vesicles formed by pinching off of the plasmalemmal invaginations and (3) discharge of the substances on the opposite surface by opening of the vesicles. Experimental studies using tracers such as ferritin (Wissig, 1958; PAlade, 1960; Jennings, Marchesi and Florey, 1962; Bruns and PALADE, 1968b) have been the most important support of this hypothesis, as labelings of caveolae and vesicles were found at various intervals after intravenous injections of tracers. The purpose of the present study is to examine whether the tracerexperiments give morphological indication of possible vesicular transport in the capillary endothelium.

\section{Methods}

Two adult rats and a mouse were used in this study. Animals were anesthetized with ether, decapitated and the abdomen was widely opened.

To fix the capillary endothelium, a polyethylene tube was inserted into the abdominal portion of the aorta. The rats were perfused with $2.5 \%$ glutaraldehyde buffered with $0.09 \mathrm{M}$ phosphate at $\mathrm{pH} 7.2$; perfusion was maintained in the first rat for about $7 \mathrm{~min}$ and in the second $30 \mathrm{~min}$. The mouse was first perfused via the polyethylene tube with physiological saline for about $2 \mathrm{~min}$, then with $1.0 \% \mathrm{OsO}_{4}$ in a phosphate buffer for about $5 \mathrm{~min}$.

After fixation with glutaraldehyde or with $\mathrm{OsO}_{4}$, about $7 \mathrm{ml}$ of ferritin (Nutritional Biochemicals Co., Cleveland, Ohio, 2x crystalline, cadmium free) was perfused via the polyethylene tube.

Labeling by ferritin-particles in the fixed capillary was examined by electron microscopy. Small pieces of muscular tissues (the adductor longus and brevis) were obtained from the thigh, fixed anew with $1.0 \% \mathrm{OsO}_{4}$ in a $0.75 \mathrm{M}$ phosphate buffer for about $3 \mathrm{hrs}$, dehydrated through a graded series of ethanol, treated with propylene oxide and embedded in Luft's Epon. With glass knives, ultrathin sections were cut on a Porter-Blum MT-1 microtome, mounted on copper grids, and contrasted with 
Millonig's lead. Photographs were obtained on a Hitachi HU-125 DS electron microscope.

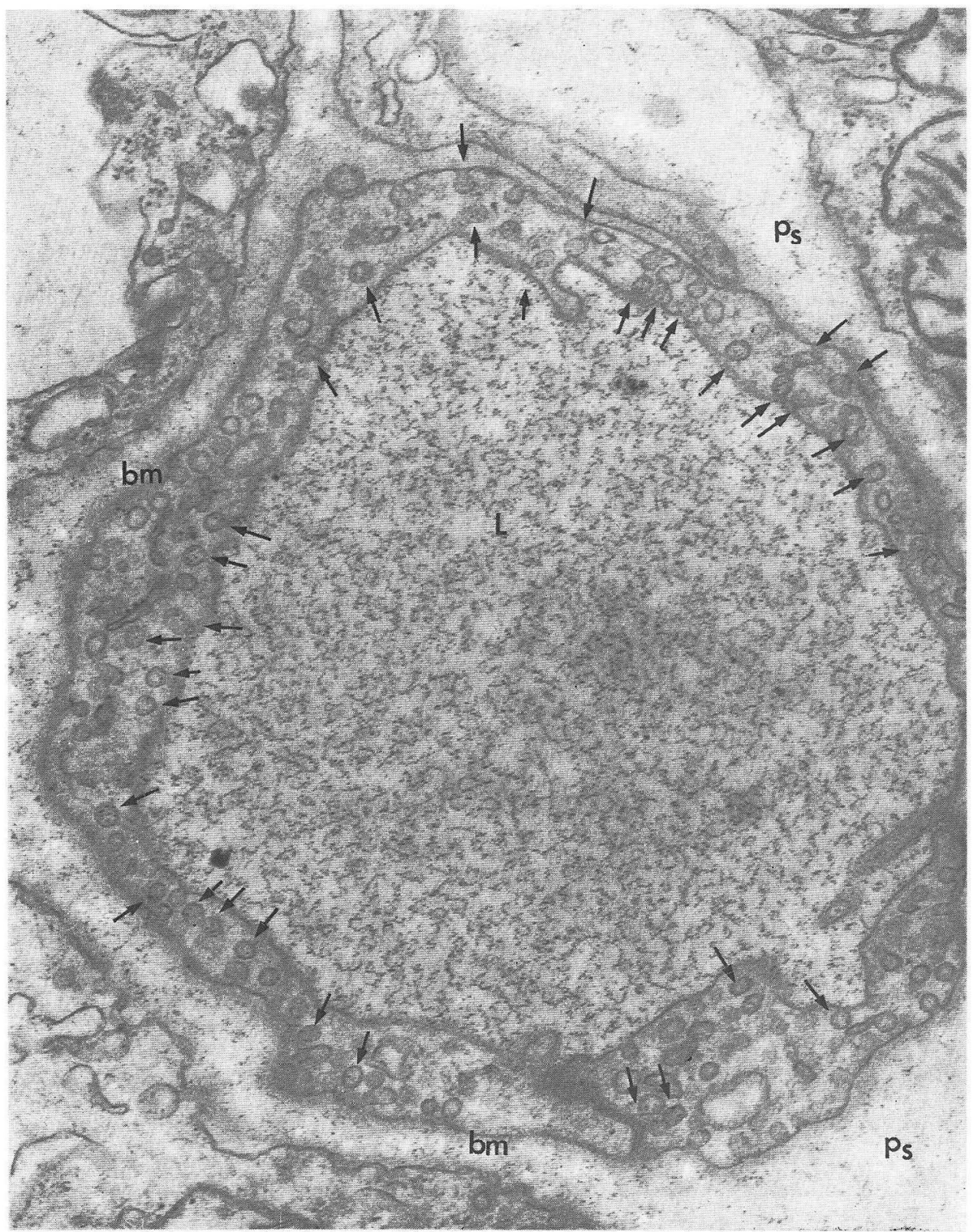

Fig. 1. A muscle capillary from the thigh of the mouse. Ferritin was injected after perfusion with $\mathrm{OsO}_{4}$ for about $5 \mathrm{~min}$. Ferritin is present in the lumen $(L)$, in the endothelium where it is restricted to caveolae and vesicles (arrows), and in the pericapillary space $(\mathrm{ps})$ and in the basement membrane $(\mathrm{bm})$. 


\section{Observations}

Under the electron microscope, the capillary wall both in the rats and the mouse consisted of non-fenestrated endothelium, continuous basement membrane and adventitial elements such as pericytes and collagenous fibers, as reviewed by previous authors (Bennett, Luft and Hampton, 1959; Majno, 1965; Bruns and Palade, 1968a). Numerous caveolae and vesicles were recognized in the endothelial cells.

In every animal examined, ferritin-particles were most abundantly seen in the capillary lumen. They were also dispersed in the pericapillary space and basement membrane. A part of the caveolae and vesicles of the endothelium was labeled by one or several ferritin-particles. The Golgi complex, lysosomes, granular endoplasmic reticulum and other cell organelles in the endothelium did not contain ferritin.

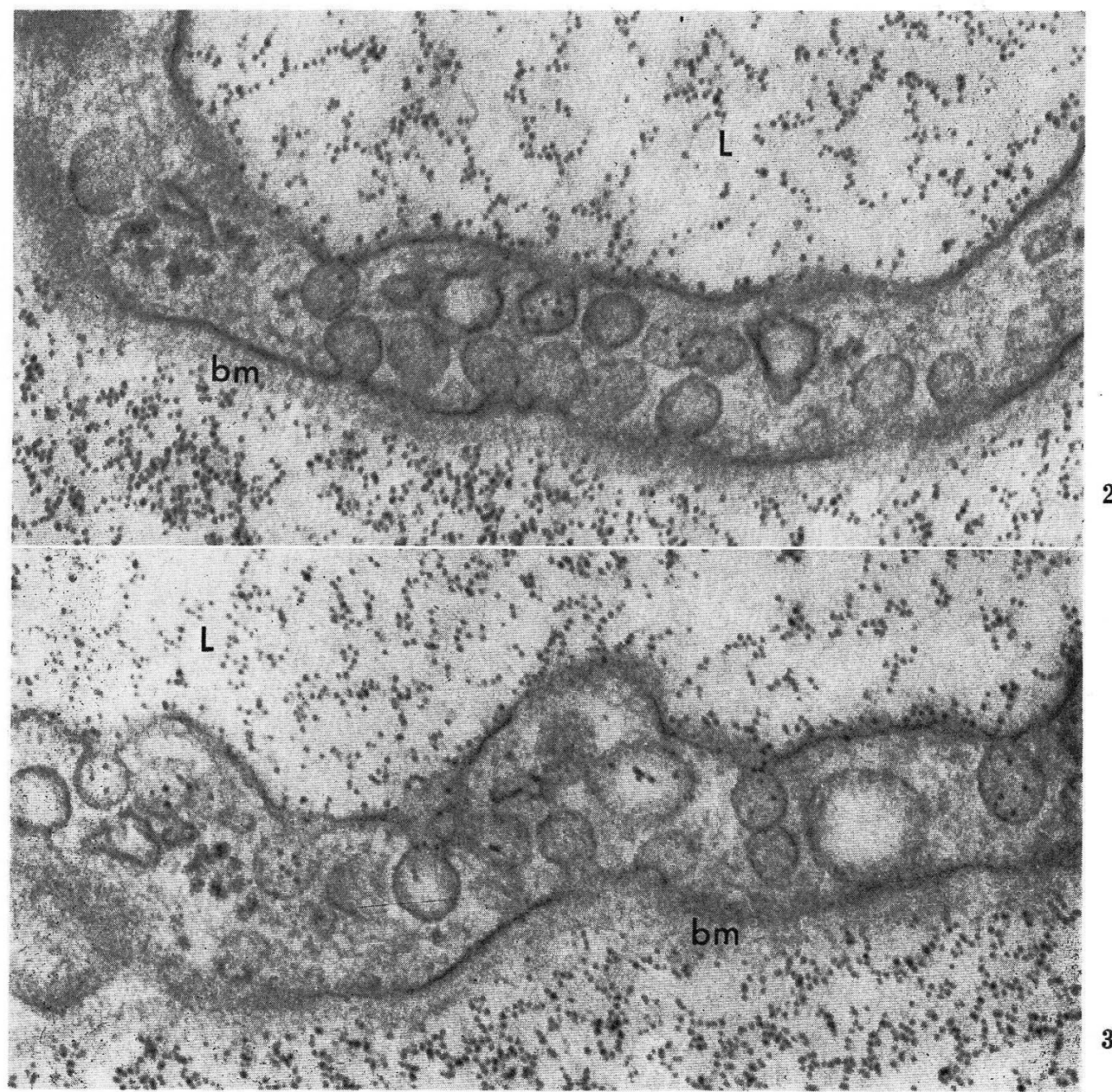

Fig. 2 and 3. Portions of a muscle capillary from the same section as Fig. 1. Note ferritin-particles within caveolae and vesicles in the endothelium. bm Basement membrane. $\times 140,000$ 
Population of ferritin differed considerably from capillary to capillary even in closely adjacent areas of the same section. The labeling by ferritin generally was more common in the mouse fixed with $\mathrm{OsO}_{4}$ before ferritin injection than in the rats fixed with glutaraldehyde.

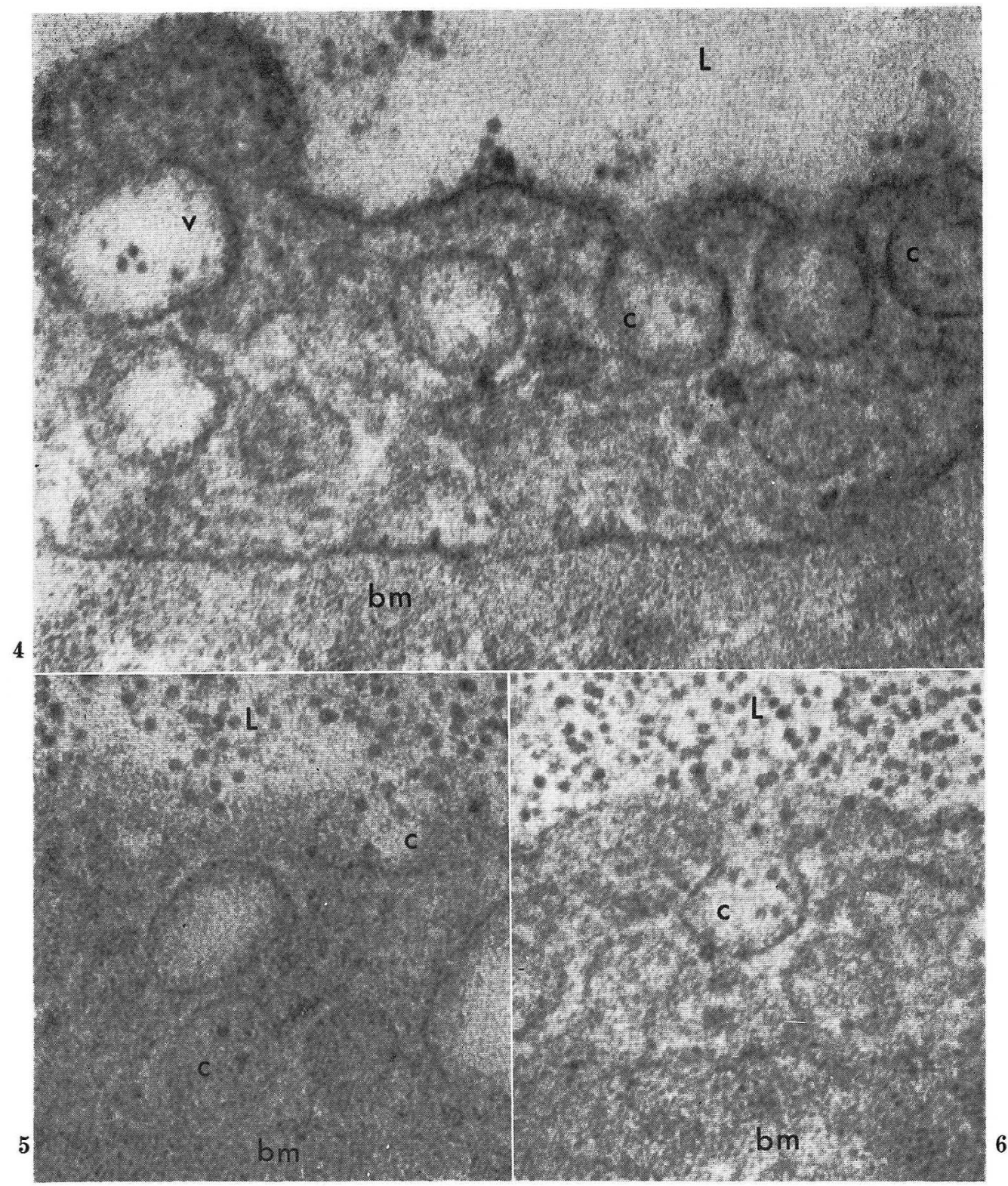

Fig. 4, 5 and 6. Portions of muscle capillaries from rats perfused with ferritin after perfusion fixation with glutaraldehyde for 7-30 min. Ferritin-particles are present within caveolae $(c)$ and vesicles $(v)$ of the endothelium. Note the structural detail of ferritin-particles. $\quad \times 330,000$ 


\section{Discussion}

Perfusion fixation with glutaraldehyde for 7-30 min or with $\mathrm{OsO}_{4}$ for 5 min seems to be sufficient to kill the endothelial cell and to stop its membrane flow. In the present material, when reached by ferritin, the caveolae and vesicles of the endothelium had most likely been fixed.

Localization of ferritin observed in the present material, nevertheless, resembles that described in the experimental studies injecting tracers into living capillaries (Jennings, Marchesi and Florey, 1962; Bruns and Palade, 1968b). The only difference seems to be that no ferritin was detected within the lysosomes of the endothelium in the present study, though it was found there in the latter type of experiment (PALAdE, 1960; Bruns and Palade, 1968b). The present finding on the ferritin labeling of prefixed endothelial vesicles is believed to provide an evidence that the previous tracer-experiments (WIssig, 1958; PALAdE, 1960; Jennings, Marchesi and Florey, 1962; BRuns and Palade, 1968b, a.o.) are no longer valid as the basis of the theory of vesicular transport.

LuFT (1966) and KARNovsKy (1967) reported that, when tissue blocks are dipped in a fixative containing ruthenium red or lanthanum before embedding, these heavy metals permeate from the periphery to the center of the tissue block through the extra-cellular space. It was proposed that this experiment serves as an examination as to whether a given space is extra-cellular or not. It may be possible that in the previous tracer-experiments ferritin and other tracers were dispersed through the extracellular space like ruthenium red and lanthanum.

The vesicular transport or cytopempsis can not be denied only on the basis of the present experiment. However, it may be worthy of mention that it has been discussed that this process is less efficient than substance permeation through intercellular clefts (LuFT, 1966; KaRNOvSKY, 1967) or via vesicular channels established from one cell front to another (KoBAYASHI, 1970). Furthermore, most physiologists have been of the opinion that vesicular transport could not account for the rapid transcapillary exchange of substances (see LANDIS and PAPPENHEIMER, 1963). Further studies must be done to reveal the real pathway by which substances penetrate the capillary endothelium.

\section{Summary}

The significance of tracer-experiments as the basis of the theory of vesicular transport or cytopempsis in the capillary endothelium was re-examined. Labeling by ferritin was studied under the electron microscope in the muscle capillaries of the rat and the mouse which were fixed beforehand by perfusion with glutaraldehyde or with $\mathrm{OsO}_{4}$. Virtually all caveolae and vesicles of the endothelium were labeled by ferritin-particles. Ferritin was also found in the pericapillary space and basement membrane.

The previous tracer-experiments are believed to indicate not an active membrane flow of cells but only a dispersion of particulate substances through the extracellular spaces and into the vesicular structures of cells opening to them. 


\section{フェリチンによる固定された筋の毛細血管の標識. 従来の標識実験は毛細血管 内皮における膜流動による物質輸送の根拠になるか（内容自抄）}

標識実験が 毛細血管内皮における膜流動による物質輸送の証明になりらるかどうか を再検討するために，ラットとマウスの下肢をグルタールアルデヒドか オスミウム酸 であらかじめ灌流固定してのち フェリチンを灌流し，筋肉の毛細血管を 電子顕微鏡下 に観察した.

この実験で, 固定された毛細血管壁でも 組織間隙, 基底膜のみならず, ほとんどすべ ての小䈑と小胞もまたフェリチンにより標識されることがわかった。

このことより，従来の標識実験では 標識物質が拡散により内皮細胞の膜構造を標識 した可能性があり，毛細血管内皮における膜流動による物質輸送が証明されたことにな らないと結論された。

\section{References}

Bennett, H. S., J. H. Luft and J. C. Hampton: Morphological classification of vertebrate blood capillaries. Amer. J. Physiol. 196: 381-390 (1959).

Bruns, R. R. and G. E. Palade: Studies on blood capillaries. I. General organization of blood capillaries in muscle. J. Cell Biol. 37: 244-276 (1968a).

: Studies on blood capillaries. II. Transport of ferritin molecules across the wall of muscle capillaries. J. Cell Biol. 37: 277-299 (1968b).

Jennings, M. A., V. T. Marchesi and H. Florey: The transport of particles across the walls of small blood vessels. Proc. Roy. Soc. B. 156: 14-19 (1962).

Karnovsky, M. J.: The ultrastructural basis of capillary permeability studied with peroxidase as a tracer. J. Cell Biol. 35: 213-236 (1967).

Kobayashi, S.: Occurrence of unique colloidal particles in snake blood and their transport across the capillary wall. A proposal of a new hypothesis on the permeability of the blood capillaries. Arch. histol. jap. 31: 511-528 (1970).

Landis, E. M. and J. R. Pappenheimer: Exchange of substances through the capillary walls. In: (ed. by) W. F. Hamilton and P. Dow: Handbook of Physiology 2, Circulation II. Washington, Williams \& Wilkins, 1963. (p. 961-1034).

Luft, J. H.: Fine structure of capillary and endocapillary layer as revealed by ruthenium red. Fed. Proc. 25: 1773-1783 (1966).

Majno, G.: Ultrastructure of the vascular membrane. In: (ed. by) W. F. Hamilton and P. Dow: Handbook of Physiology 2, Circulation III. Washington, Williams \& Wilkins, 1965. (p. 2293-2375).

Moore, D. H. and H. Ruska: Fine structure of capillaries and small arteries J. biophys. biochem. Cytol. 3: 457-462 (1957).

Palade, G. E.: The fine structure of blood capillaries. J. appl. Physics 24: 1424 (1953).

: Transport in quanta across the endothelium of blood capillaries. Anat. Rec. 136: 254 (1960).

Wissig, S. L.: An electron microscope study of the permeability of capillaries in muscle. Anat. Rec. 130: 467 (1958).

小 林 繁
干951 新渴市旭町 1
新潟大学医学部第三解剖学教室
Dr. Shigeru Koвayashi

Department of Anatomy

Niigata University School of Medicine

951 Niigata, Japan 